\title{
Effectof Unit Hydrographs and Rainfall Hyetographs on Critical Rainfall Estimates of Flash Flood
}

\author{
Fanzhe Kong $\mathbb{D}^{\mathbb{D}}$, Wei Huang, Zhilin Wang, and Xiaomeng Song \\ School of Resources and Geosciences, China University of Mining and Technology, Xuzhou 221116, China \\ Correspondence should be addressed to Fanzhe Kong; kongfz3@126.com
}

Received 13 November 2019; Revised 27 January 2020; Accepted 23 May 2020; Published 10 June 2020

Academic Editor: Stefano Federico

Copyright (c) 2020 Fanzhe Kong et al. This is an open access article distributed under the Creative Commons Attribution License, which permits unrestricted use, distribution, and reproduction in any medium, provided the original work is properly cited.

\begin{abstract}
To obtain critical rainfall (CR) estimates similar to the rainfall value that causes minor basin outlet flooding, and to reduce the flash flood warning missed/false alarm rate, the effect of unit hydrographs (UHs) and rainfall hyetographs on computed threshold rainfall (TR) values was investigated. The Tanjia River basin which is a headwater subbasin of the Greater Huai River basin in China was selected as study basin. Xin'anjiang Model, with subbasins as computation units, was constructed, and time-variant distributed unit hydrographs (TVUHs) were used to route the channel network concentration. Calibrated Xin'anjiang Model was employed to derive the TVUHs and to obtain the maximum critical rainfall duration $\left(D_{\max }\right)$ of the study basin. Initial soil moisture condition was represented by the antecedent precipitation index $(\mathrm{Pa})$. Rainfall hyetographs characterized by linearly increasing, linearly decreasing, and uniform hyetographs were used. Different combinations of the three hyetographs and UHs including TVUHs and time-invariant unit hydrographs (TIVUHs) were utilized as input to the calibrated Xin'anjiang Model to compute the relationships between TR and $\mathrm{Pa}$ (TR-Pa curves) by using trial and error methodology. The computed TR-Pa curves reveal that, for given $\mathrm{Pa}$ and $\mathrm{UH}$, the TR corresponding to linearly increasing hyetograph is the minimum one. So, the linearly increasing hyetograph is the optimum hyetograph type for estimating CR. In the linearly increasing hyetograph context, a comparison was performed between TR-Pa curves computed from different UHs. The results show that TR values for different TIVUHs are significantly different and the TR-Pa curve gradient of TVUHs is lower than that of TIVUHs. It is observed that CR corresponds to the combination of linearly increasing hyetograph and TVUHs. The relationship between CR and Pa (CR-Pa curves) and that between CR and duration $(D)$ (CR-D curves) were computed. Warnings for 12 historical flood events were performed. Warning results show that the success rate was $91.67 \%$ and that the critical success index (CSI) was 0.91 . It is concluded that the combination of linearly increasing hyetograph and TVUHs can provide the CR estimate similar to the minimum rainfall value necessary to cause flash flooding.
\end{abstract}

\section{Introduction}

Flooding is the worst weather-related hazard, causing loss of life and excessive property damage [1-3]. In general, flash floods are characterized by their rapid onset, leaving very limited effective response opportunities [3-5]. Flood damage mitigation is provided through a variety of structural and nonstructural methods. A significant nonstructural method is the operation of flood warning systems [1].

Currently, three criteria are used for an expected flooding determination: critical discharge, critical runoff, and critical rainfall (CR). Critical rainfall criterion is used by most flood warning systems [3, 6-9].
Given an initial soil moisture condition and a rainfall duration $(D)$, different hyetographs show the diverse areal rainfall volumes over the study basin necessary to cause minor basin outlet flooding which is defined as threshold rainfall (TR), and the minimum of these TR values is referred to as CR. That is to say, TR is a function of initial soil moisture condition, rainfall duration, and the form of rainfall hyetograph, but CR is a function of only initial soil moisture condition and rainfall duration.

By comparing real-time observed or predicted rainfall volume of a given duration to the CR value, the CR-based flood warning systems decide whether to issue a warning. For early warning, the consequences of under- or 
overestimating the $\mathrm{CR}$ value are extremely different. Adopting a CR value higher than the rainfall volume that actually produces flood damage leads to missing such events and failure to issue an alarm. Underestimating the CR may instead determine the issue of false alarms [10]. For flood warning systems development, it is important to obtain as accurate as possible CR estimates. The most significant way to reduce missed/false alarm rate is to have the CR estimates be comparable to the minimum rainfall value necessary to cause flooding.

The false warning costs are commonly not only much lower than the avoidable flood loss, but also cannot match up to indirect and/or intangible flood damages such as serious injury or loss of life $[11,12]$. So considering that an error will always be present, it is better to underpredict rather than overpredict the CR estimate for safety reasons [10].

Currently, there are three CR value computation methods: inverse, positive, and empirical. The Flash Flood Guidance (FFG) system [6] is representative of an inverse method. The computational process of FFG is divided into three steps. First, the critical discharge value is estimated. In the second step, threshold runoff estimates for various rainfall durations are obtained based on critical discharge and unit hydrograph (UH) peak, which belongs to runoff concentration computation of hydrology. In the third step, the FFGs are obtained based on threshold runoff values where the rainfall vs. runoff curves as a function of soil moisture conditions are needed [13], which belongs to runoff generation computation of hydrology. A significant disadvantage of FFG is that uniform rainfall over rainfall duration is presumed [14].

The empirical methods are based on historical rainfall and streamflow data [15]. Miao et al. [15] proposed an empirical method to determine TR value by using a linear binary classification based on long-term historical rainfall and flood data. Enough flood event data are necessary to derive the binary classification. So this method cannot be implemented in ungauged basins.

The positive methods based on a watershed hydrological model estimate the TR values from critical discharge by trial and error $[16,17]$. The hydrological responses of different cumulative rainfall values, for fixed duration, initial soil moisture condition, and hyetograph type, are simulated by calibrated watershed hydrological model. The cumulative rainfall value generating the critical discharge is taken as the TR estimate. The computation process of the positive method has an explicit hydrology theoretical basis, so the disadvantages inherent in the inverse method may be overcome. In this study, the calibrated Xin'anjiang Model with its subbasins being used as computation units [18] is employed to compute TR and CR values.

Montesarchio et al. [3] estimated TR values for the Mignone River cross section using an entropy-based decision approach and a simulation approach based on radar data and rain gauge data. Results show that the TR values computed using various methods are obviously different and that, for the fixed watershed hydrological model, the type of rainfall data source used for model calibration significantly affects the TR estimates.
According to hydrological rainfall-runoff formation theory, for a fixed computing method, the TR estimate is generally a function of initial soil moisture condition, rainfall duration, and hyetograph. The effect of initial soil moisture conditions has been taken into account in the vast majority of current methods $[6,7,16,17,19,20]$. In [6], the rainfall vs. runoff curves were taken as a function of initial soil moisture content to take into account the effect of initial soil moisture conditions on TR estimates. In $[3,7,16]$, initial soil moisture conditions were classified into antecedent moisture classes AMC I, AMC II, and AMC III, representing dry soil, moderately saturated soil, and wet soil, according to the total amount of accumulative rain. In [17], the initial soil moisture conditions were taken into account by imposing an initial discharge value of the watershed hydrological model, and the effect of different initial conditions is analyzed by varying the initial discharge in the model simulations. In [19], a probability distributed moisture model was used to estimate the soil moisture content as the initial soil moisture condition of a rainfall-runoff model employed to compute TR values. In [20], both AMC and antecedent precipitation index (API) were utilized to estimate the initial soil conditions.

Given an initial soil moisture condition, for the same rainfall volume, the hydrographs and peak discharge rates may be significantly different when different rainfall hyetographs are adopted $[16,17,21]$. Consequently, for the same initial soil moisture conditions, various hyetograph types result in different TR values $[16,17]$. In $[17,21]$, three synthetic hyetograph types characterized by linearly increasing intensity, decreasing intensity, and linearly increasing-decreasing intensity were employed to investigate the effect of rainfall hyetograph type on the hydrograph at given rainfall volume. In [16], four standards hyetographs including step hyetograph, triangular increasing rate hyetograph, triangular decreasing rate hyetograph, and isosceles triangular hyetograph were used to analyze the effect of rain type on TR estimates. If the hyetograph type corresponding to the minimum rainfall necessary to cause flooding is found, it can be used to directly compute CR value. So determining the hyetograph type corresponding to the minimum rainfall to cause flooding is one objective of this work.

No matter whether an inverse or positive method is used, TR values are always computed by routing surface runoff using the UH method $[1,6,17,19,22]$. So deriving the UHs representing the true basin concentration characteristics is a key to calculating the CR estimate matching the minor rainfall value necessary to cause flooding. For more than 75 years since the inception of UH theory was presented by Sherman, it is still one of the most widely used methods for flood prediction and warning system development in gauged basins with observed rainfall and runoff data, but this datadriven traditional approach limits the UH derivation only to gauged watersheds. Synthetic UHs may only be used in basins whose hydrographs have a single peak [23-25]. Geomorphologic UHs, regardless of time-invariant (TIVUH) [26-31] or time-variant (TVUH) [32, 33], do not take the dynamic factor (flow velocity) spatial distribution 
into account. Distributed UHs based on a spatially distributed velocity field can adequately take the nonuniformity of basin characteristics into account [34-36]. Formulas defined as a function of rainfall intensity are adopted to compute spatially distributed velocity fields so as to derive TVUHs $[18,37,38]$ that can solve to a certain extent the nonlinear problem of runoff concentration.

For a fixed runoff generation computing method, different rainfall-runoff transformation methods may lead to different TR estimates. By doing this work, investigating the effect of UHs on TR estimates and suggesting a reasonable $\mathrm{UH}$ used in computing $\mathrm{CR}$ value is another study objective.

In this study, three rainfall hyetograph types (linearly increasing, linearly decreasing, and uniform) and two $\mathrm{UH}$ types (TIVUHs and TVUHs) are used to investigate the effects of hyetographs and UHs on TR/CR estimates and warning results. The objectives are (1) to explain, for fixed duration and initial conditions, that rainfall hyetographs and UHs significantly affect the TR estimates; (2) to suggest that the rainfall hyetograph type leading to minimum TR estimate and the $\mathrm{UH}$ resulting in optimal simulation results should be adopted to compute CR estimates; and (3) to propose a method for CR computation.

Determining TR and CR value is a hydrological problem. The uncertainties of TR and CR estimates related principally to the method (including runoff generation and runoff concentration), parameters, data sources (including rainfall and discharge), and adopted rainfall hyetograph types $[3,16,17,21]$. In this work, the method based on watershed hydrological model was used. For the fixed study watershed and data sources (observed data), in order to obtain the CR estimate approximate as far as possible with the minimum rainfall value necessary to cause flooding, the appropriate model (Xin'anjiang Model and UHs) and opportunely calibrated parameters were employed. For nonlinear types, no matter increasing or decreasing, the forms of rainfall hyetograph are innumerable. In this study, the linearly change hyetograph types were used. In fact, the rainfall hyetograph corresponding to the minimum rainfall value causing flooding is nonlinear.

This paper consists of six sections: Section 2 introduces the methods used in the study including the watershed hydrological model structure, TR and CR computation methods, and warning system assessment method. Section 3 describes the study basin and model calibration. Section 4 introduces the computation process and results of CR. In Section 5, the application of CR values in warnings historical flood event is performed. Finally, some conclusions are presented in Section 6.

\section{Methods}

\subsection{Watershed Hydrological Model}

2.1.1. Structure of Model. The Xin'anjiang Model is employed in this study and the basin is divided into a series of subbasins as computation units. Runoff generation and flow concentration computations are performed within the subbasins and the runoff from each subbasin is routed to the main basin outlet. The total hydrograph at the main basin outlet is equal to the sum of all subbasin hydrographs.

2.1.2. Rainfall Computation Component. The Kriging interpolation method is used to derive rainfall depth of all cells within subbasins from that of rainfall gauges. Mean areal rainfall values of each subbasin are computed by arithmetic mean method using rainfall depth for all cells within the subbasin.

2.1.3. Runoff Generation Computation Component. A tension water storage capacity curve, also named a parabolic curve, is used to represent the nonuniform distribution of tension water storage capacity and to compute the runoff value. The computational equations are as follows:

$$
a=\mathrm{WMM}\left[1-\left(1-\frac{W}{\mathrm{WM}}\right)^{1 / 1+b}\right]
$$

when $a+\mathrm{PE} \leq \mathrm{WMM}$,

$$
R=\mathrm{PE}+W-\mathrm{WM}+\mathrm{WM}\left(1-\frac{\mathrm{PE}+a}{\mathrm{WMM}}\right)^{1 / 1+b},
$$

when $a+\mathrm{PE} \geq \mathrm{WMM}$,

$$
R=\mathrm{PE}+W-\mathrm{WM},
$$

where $\mathrm{PE}$ is the rainfall value, $\mathrm{mm} ; R$ is the runoff value, $\mathrm{mm}$; $W$ is the mean areal tension water storage, $\mathrm{mm}$; WM is the mean areal tension water storage capacity, $\mathrm{mm}$; WMM is the maximum tension water storage capacity of the watershed, $\mathrm{mm}$; and $b$ is the tension water capacity distribution curve exponent (parabolic curve).

A free water storage capacity curve is used to represent the nonuniform distribution of free water storage capacity over runoff-producing areas and to separate runoff $R$ into surface flow, interflow, and groundwater. Computational equations are as follows:

$$
\mathrm{AU}=\mathrm{SMM}\left[1-\left(1-\frac{S}{\mathrm{SM}}\right)^{1 / 1+\mathrm{EX}}\right],
$$

when $\mathrm{PE}+\mathrm{AU} \leq \mathrm{SMM}$,

$$
\mathrm{RS}=\left\{\mathrm{PE}-\mathrm{SM}+\mathrm{S}+\mathrm{SM}\left[1-\frac{(\mathrm{PE}+\mathrm{AU})}{\mathrm{SMM}}\right]^{1+\mathrm{EX}}\right\} \mathrm{FR},
$$

$$
\begin{aligned}
\mathrm{RI} & =(\mathrm{PE}+S-\mathrm{RS}) \mathrm{KI} \cdot \mathrm{FR}, \\
\mathrm{RG} & =(\mathrm{PE}+S-\mathrm{RS}) \mathrm{KG} \cdot \mathrm{FR},
\end{aligned}
$$

when $P E+A U \geq S M M$,

$$
\mathrm{RS}=(\mathrm{PE}+S-\mathrm{SM}) \mathrm{FR},
$$




$$
\begin{aligned}
\mathrm{RI} & =\mathrm{SM} \cdot \mathrm{KI} \cdot \mathrm{FR}, \\
\mathrm{RG} & =\mathrm{SM} \cdot \mathrm{KG} \cdot \mathrm{FR},
\end{aligned}
$$

where PE is the rainfall value (equal to excess rainfall $R$ in the runoff-producing area), $\mathrm{mm}$; RS, RI, and RG are surface flow, interflow, and groundwater, respectively, $\mathrm{mm}$; $S$ is the equivalent free water storage over the runoff-producing area, $\mathrm{mm}$; SM is the area mean free water storage capacity (maximum possible deficit of free water storage), $\mathrm{mm}$; EX is the free water storage capacity curve exponent (parabolic curve); SMM is the maximum watershed free water storage capacity, mm; FR is runoff-producing area; KI is the outflow coefficient of free water storage to interflow; and KG is the outflow coefficient of free water storage to groundwater.

Estimating initial soil moisture conditions is necessary for runoff generation computation. In this study, the antecedent precipitation index $(\mathrm{Pa})$, used in the past as a moisture content indicator, is used and calculated at the beginning of every storm event as follows:

$$
P_{a, i+1}=P_{i+1}+k P_{a, i} \text {, }
$$

where $P_{a, i}$ is the antecedent precipitation index, $\mathrm{mm} ; P$ is daily rainfall, $\mathrm{mm} ; i$ is day of estimate; and $k$ is depletion constant (in this study, $k=0.83$ [39]).

Because the tension water storage capacity curve is a parabolic type, the relationship between $\mathrm{Pa}$ and $\mathrm{W}$ is as follows:

$$
P_{a}=\mathrm{WMM}\left[1-\left(1-\frac{W}{\mathrm{WM}}\right)^{1 / 1+b}\right] .
$$

\subsubsection{Concentration Computation Components}

(1). Hillside concentration. The surface flow passing directly into the channel systems is treated as TRS, and the interflow $\mathrm{RI}$ and groundwater RG are routed through linear reservoirs into channel systems as TRI and TRG. The computational equations are as follows:

$$
\begin{aligned}
\operatorname{TRS}(t) & =\operatorname{RS}(t) \cdot U, \\
\operatorname{TRI}(t) & =\operatorname{TRI}(t-1) \cdot \mathrm{CI}+\mathrm{RI}(t) \cdot(1-\mathrm{CI}) \cdot U, \\
\operatorname{TRG}(t) & =\operatorname{TRG}(t-1) \cdot \mathrm{CG}+\mathrm{RG}(t) \cdot(1-\mathrm{CG}) \cdot U, \\
\operatorname{TTR}(t) & =\operatorname{TRS}(t)+\operatorname{TRI}(t)+\operatorname{TRG}(t),
\end{aligned}
$$

where TRS, TRI, and TRG are inflow into channel systems of surface flow, interflow, and groundwater, respectively, $\mathrm{m}^{3} / \mathrm{s}$; TTR is the total inflow, $\mathrm{m}^{3} / \mathrm{s}$; $U$ is the transformation coefficient transforming runoff depth to discharge rate, $U=F /(3.6 \Delta t)$, where $F$ is the drainage area, $\mathrm{km}^{2}$, and $\Delta t$ is computational time interval, $\mathrm{h}$; $\mathrm{CI}$ is the recession constant of interflow storage; $\mathrm{CG}$ is the recession constant of groundwater storage.

(2). Channel network concentration. The channel network routing within a subbasin is represented by convolution of $\operatorname{TTR}(t)$ with a dimensionless $\mathrm{UH}$ as follows:

$$
\mathrm{Q}(t)=\sum_{i=1}^{N} \mathrm{UH}(i) \cdot \operatorname{TTR}(t-i+1)
$$

where $Q(t)$ is the subbasin outlet discharge rate, $\mathrm{m}^{3} / \mathrm{s}$; $\mathrm{UH}$ is the ordinate of dimensionless unit hydrograph; and $N$ is the number of dimensionless UH time intervals. The method presented by Kong et al. [18] is used to derive the TVUHs of each subbasin.

Given a velocity within a cell of DEM, the travel time through the cell is computed as follows:

$$
\begin{gathered}
\tau_{k}=\frac{L}{V_{k}}, \\
\text { or } \tau_{k}=\frac{\sqrt{2} L}{V_{k}},
\end{gathered}
$$

where $\tau_{k}$ is the travel time within cell $k, \mathrm{~s} ; L$ is cell size, $\mathrm{m}$; and $V_{\mathrm{k}}$ is the velocity within cell $k, \mathrm{~m} / \mathrm{s}$. The travel time of a cell to subbasin outlet is computed as follows:

$$
T_{j}=\sum_{k=1}^{m} \tau_{k}
$$

where $T_{j}$ is the travel time of cell $j$ to the subbasin outlet, $s ; m$ is the number of cells along the drainage network to subbasin outlet; $\tau_{k}$ is the travel time within cell $k$, s.

Based on the travel time of all cells to the subbasin outlet, the S-hydrograph of dimensionless UH can be obtained as follows:

$$
S_{t}=\frac{1}{F} \sum_{j=1}^{n} A_{j}, \quad\left(T_{j} \leq t\right),
$$

where $S_{t}$ is the ordinate value of S-hydrograph at time $t ; F$ is the subbasin area, $\mathrm{km}^{2} ; A_{j}$ is the area of cell $j, \mathrm{~km}^{2}$; and $n$ is the number of cells whose $T$ being less than or equal to $t$. The ordinate of dimensionless $\mathrm{UH}$ is computed as follows:

$$
\mathrm{UH}(t)=S_{t}-S_{t-\Delta t},
$$

where $\Delta t$ is computational time interval, h.

It can be seen that the key to obtain $\mathrm{UH}$ is deriving the velocity of each cell. The fundamental equation form used to compute velocity is as follows:

$$
V=k S^{0.5}
$$

where $k$ is a coefficient based on the flow type; Sorrell et al. [40] provide values of $k$ for several flow types; and $S$ is the flow path slope.

To take the effect of excess rainfall intensity on velocity into account, equation (17) is modified as follows:

$$
V=k S^{0.5}\left(\frac{i}{i_{0}}\right)^{c}
$$

where $i$ is the excess rainfall intensity, $\mathrm{mm} / \mathrm{h} ; i_{0}$ is the excess rainfall intensity corresponding to the coefficient $k$, determined by calibration; and $c$ is a parameter, on the basis of literature $[37,38]$, with 0.4 being adopted. 
Equation (18) can not only take into account the effect of excess rainfall intensity on velocity, but also can employ the values of $k$ provided by Sorrell et al. [40].

By using equation (18), the time-variant spatially distributed velocity fields and TVUHs of different rainfall duration in a rainfall event are derived.

2.1.5. Channel Routing Method. The dynamic Muskingum method presented by Tewolde et al. [41] is used to route channel flow from subbasin outlets to the basin outlet.

\subsection{CR Computation Method}

2.2.1. TR Computation. TR estimate (mean areal rainfall value) depends on not only $D$ and $\mathrm{Pa}$, but also rainfall hyetograph and computation methods (runoff concentration). For a given $\mathrm{Pa}$, the TR value of $D$ is not unique. A primary goal of this study is to investigate the influence of rainfall hyetographs and runoff concentration computation methods on the TR estimates. Using the watershed hydrological model above, TR values are computed by trial and error.

For a given $D$ (taken as an integer multiple of $\Delta \mathrm{t}$ ), $\mathrm{Pa}$, and a combination of hyetograph type and $\mathrm{UH}$, computation steps of TR value are as follows: (1) $D$ is divided into $n$ time intervals; (2) according to the hyetograph, the proportion of each time interval rainfall to total rainfall of $D(P)$ is determined; (3) trial and error: for a given $P$, running hydrological model to derive discharge hydrograph and comparing peak rate and critical discharge value. The $P$ making the computed peak rate equal or close to critical discharge value is taken as the TR value.

2.2.2. CR Computation. CR is related only to $D$ and $P$ a. For a given $\mathrm{Pa}$ and $D$ combination, the minimum of all TR values is taken as the $\mathrm{CR}$ value. The relationship between $\mathrm{CR}$ and $\mathrm{Pa}$ of different $D$ and the relationship between CR and $D$ of different $\mathrm{Pa}$ are obtained, being the basis of flash flood warning.

2.3. Representation of Warning Results. The contingency table (Table 1) shows four possible results for a single flash flood warning, $\mathrm{X}$ denotes an event occurred and warning was issued (hits), $\mathrm{Y}$ denotes an event occurred but warning was not issued (missed events), $\mathrm{Z}$ denotes an event did not occur but warning was issued (false alarms), and $\mathrm{W}$ denotes an event did not occur and warning was not issued.

2.4. Assessment of a Warning System. Table 2 shows the statistics of flash flood warning results, and $N_{\mathrm{X}}, N_{\mathrm{Y}}, N_{\mathrm{Z}}$, and $N_{\mathrm{W}}$ represent the number of $\mathrm{X}, \mathrm{Y}, \mathrm{Z}$, and $\mathrm{W}$, respectively.
TABLE 1: Two-by-two contingency table of the warning results for an event.

\begin{tabular}{lcc}
\hline Observations & \multicolumn{2}{c}{ Forecasts } \\
& Warning & No warning \\
\hline Event & $\mathrm{X}$ & $\mathrm{Y}$ \\
Nonevent & $\mathrm{Z}$ & $\mathrm{W}$ \\
\hline
\end{tabular}

TABle 2: Two-by-two contingency table for the assessment of a warning system.

\begin{tabular}{lcc}
\hline Observations & \multicolumn{2}{c}{ Forecasts } \\
& Warning & No warning \\
\hline Event & $N_{\mathrm{X}}$ & $N_{\mathrm{Y}}$ \\
Nonevent & $N_{\mathrm{Z}}$ & $N_{\mathrm{W}}$ \\
\hline
\end{tabular}

Four indicators indicating the quality of warning results $[2,19,42]$ are used as follows:

$$
\begin{aligned}
\text { HAR } & =\frac{N_{\mathrm{X}}}{N_{\mathrm{X}}+N_{\mathrm{Y}}}, \\
\mathrm{MAR} & =\frac{N_{\mathrm{Y}}}{N_{\mathrm{X}}+N_{\mathrm{Y}}}, \\
\mathrm{FAR} & =\frac{N_{\mathrm{Z}}}{N_{\mathrm{X}}+N_{\mathrm{Z}}}, \\
\mathrm{CSI} & =\frac{N_{\mathrm{X}}}{N_{\mathrm{X}}+N_{\mathrm{Y}}+N_{\mathrm{Z}}},
\end{aligned}
$$

where HAR is the hit rate; MAR is the missed alarm rate; FAR is the false alarm rate; and CSI is a comprehensive critical success index reflecting the quality of warning results and its value goes from 0 to 1 . The larger the CSI value is, the better the quality is.

\section{Study Area and Model}

3.1. Basin and Data. The study area is Tanjia River basin located upstream from the Huai River basin in China with a catchment area of $173 \mathrm{~km}^{2}$ and a mean slope of 0.30 . There are five rainfall gauges within the basin and a station (Tanjiahe station) at the basin outlet as shown in Figure 1. Using DEM as a data source, ArcGIS is used to derive each cell's slope and flow direction, divide subbasins, and compute subbasin areas. DEM resolution is $30 \mathrm{~m} \times 30 \mathrm{~m}$. Data from 1954 to 2001 provided by Henan Hydrology Bureau are used in this study.

3.2. Model Calibration. In this study, $\Delta t$ is $0.5 \mathrm{~h}$. Net rainfall value of $\Delta t$ for TVUHs is $5 \mathrm{~mm}, 10 \mathrm{~mm}, 15 \mathrm{~mm}, 20 \mathrm{~mm}$, $25 \mathrm{~mm}$, and $30 \mathrm{~mm}$, with $\mathrm{UHs}$ corresponding to them being $\mathrm{UH}_{5 \mathrm{~mm}}, \mathrm{UH}_{10 \mathrm{~mm}}, \mathrm{UH}_{15 \mathrm{~mm}}, \mathrm{UH}_{20 \mathrm{~mm}}, \mathrm{UH}_{25 \mathrm{~mm}}$, and $\mathrm{UH}_{30 \mathrm{~mm}}$, respectively. In the hydrograph simulation, according to the net rainfall value calculated by runoff generation in each $\Delta t$, the corresponding $\mathrm{UH}$ is selected based on Table 3 . The calibrated hydrological model parameter values 


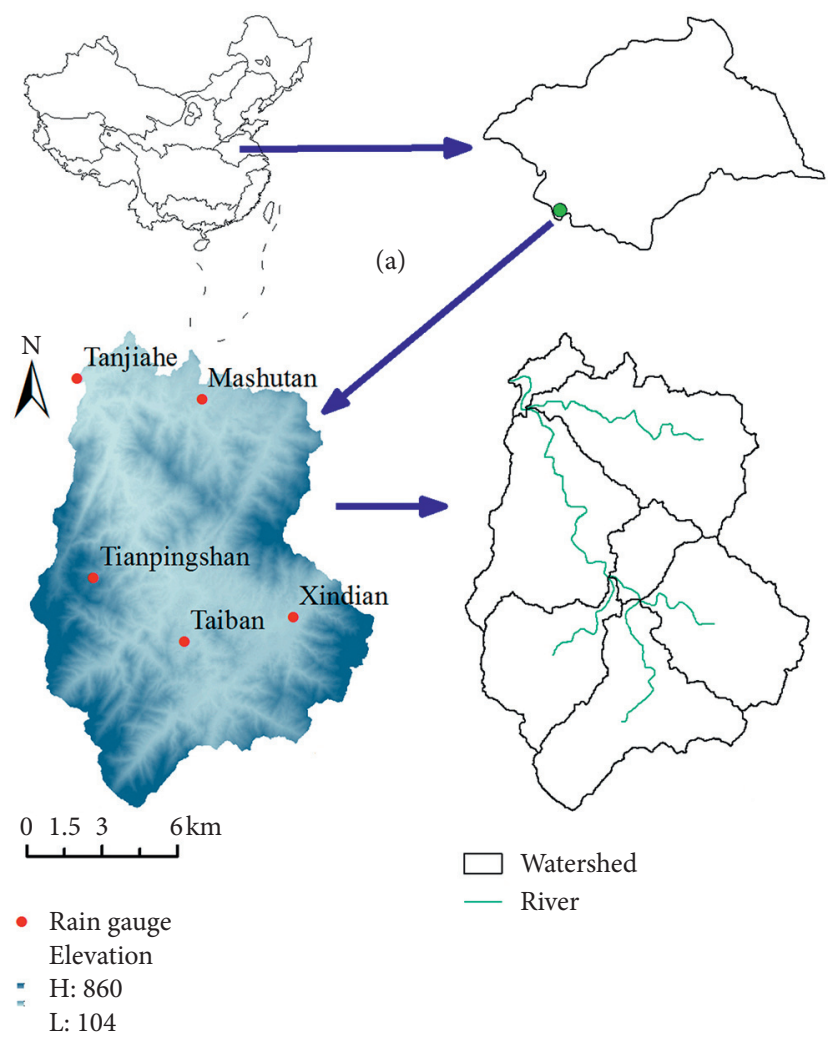

(b)

(c)

FIgURE 1: Map of the study basin with (a) basin location, (b) DEM and rainfall gauges, and (c) subbasins.

TABle 3: Excess rainfall ranges for TVUHs.

\begin{tabular}{lcccccc}
\hline$i(\mathrm{~mm} / \mathrm{h})$ & $0<i \leq 15$ & $15<i \leq 25$ & $25<i \leq 35$ & $35<i \leq 45$ & $45<i \leq 55$ & $55<i$ \\
\hline $\mathrm{UH}$ & $\mathrm{UH}_{5 \mathrm{~mm}}$ & $\mathrm{UH}_{10 \mathrm{~mm}}$ & $\mathrm{UH}_{15 \mathrm{~mm}}$ & $\mathrm{UH}_{20 \mathrm{~mm}}$ & $\mathrm{UH}_{25 \mathrm{~mm}}$ & $\mathrm{UH}_{30 \mathrm{~mm}}$ \\
\hline
\end{tabular}

TABle 4: Parameters of Xin'anjiang Model.

\begin{tabular}{lccccccccccc}
\hline WM $(\mathrm{mm})$ & WUM $(\mathrm{mm})$ & WLM $(\mathrm{mm})$ & B & C & SM $(\mathrm{mm})$ & EX & KI & KG & CI & CG & $i_{0}(\mathrm{~mm} / \mathrm{h})$ \\
\hline 100 & 20 & 60 & 0.3 & 0.13 & 30 & 1.3 & 0.3 & 0.4 & 0.1 & 0.1 & 40 \\
\hline
\end{tabular}

have been given by Kong et al. [18] as shown in Table 4 . Modeling results show that when TIVUHs are used, the best simulation results can be obtained from $\mathrm{UH}_{20 \mathrm{~mm}}$.

\section{CR Computation}

4.1. Critical Discharge Determination. It is suggested that two-year return period flow can be used as critical discharge $[1,14,43-46]$, so in this study, the two-year return period peak discharge is taken as the critical discharge. According to frequency calculation based on historical hydrological data, the calculated two-year return period peak discharge is $350 \mathrm{~m}^{3} / \mathrm{s}$, meaning the critical discharge is $350 \mathrm{~m}^{3} / \mathrm{s}$.

\subsection{Critical Rainfall Time Duration}

4.2.1. Maximum Critical Rainfall Time Duration ( $\left.D_{\max }\right)$.
According to rainfall-runoff formation theory, the $D_{\max }$ is equal to basin concentration time. When a TIVUH is adopted, the time base of UH can be used as $D_{\text {max }}$. When TVUHs are adopted, because of different net rainfall intensities corresponding to different $\mathrm{UH}$ time bases, the $\mathrm{UH}$ time base corresponding to the smallest net rainfall intensity can be taken as $D_{\max }$.

Only the rainfall of one $\Delta t$ with antecedent soil water content being saturated is used as the input to the watershed hydrological model. The hydrographs for six rainfall values of $5 \mathrm{~mm}, 10 \mathrm{~mm}, 15 \mathrm{~mm}, 20 \mathrm{~mm}, 25 \mathrm{~mm}$, and $30 \mathrm{~mm}$ are computed, respectively, as illustrated in Figure 2 (ordinate value is the ratio of discharge at each time to peak rate). Based on the linear assumption of the $\mathrm{UH}$ method, the time base of each hydrograph is equal to that of the $\mathrm{UH}$ corresponding to the same rainfall value, for example, the time base of the hydrograph for $15 \mathrm{~mm}$ is equal to that of $\mathrm{UH}_{15 \mathrm{~mm}}$. Because the time base of $\mathrm{UH}_{5 \mathrm{~mm}}$ 


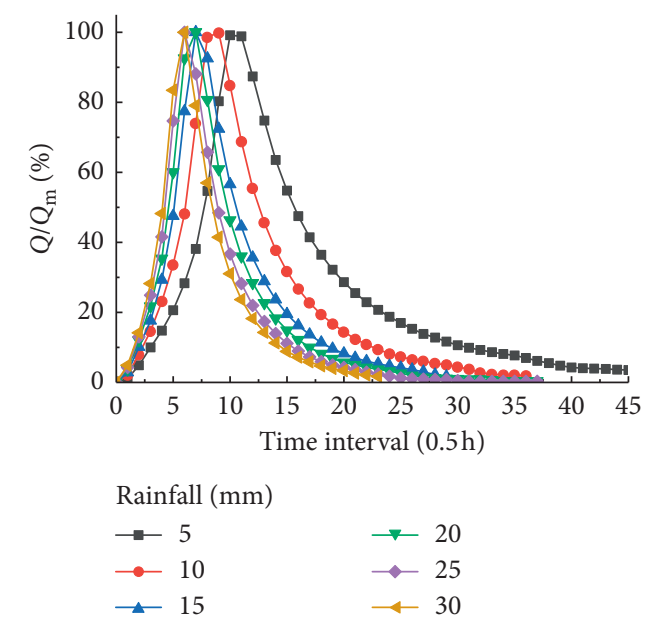

Figure 2: Hydrographs of different rainfall values.

( $24 \mathrm{~h})$ is the maximum one of six UHs, it is taken as the $D_{\max }$ of the study basin.

4.2.2. Other Critical Rainfall Time Duration. In the range of 0 to $D_{\max }$, the integral times of $\Delta t$ can be taken as the critical rainfall time duration $D$, such as $1 \mathrm{~h}, 1.5 \mathrm{~h}, 2 \mathrm{~h}$, $2.5 \mathrm{~h}, \ldots, D_{\max }$. The relationships of TR-Pa and CR-Pa are analyzed by taking $D=5 \mathrm{~h}$ as an example in the remaining of this article.

\subsection{Computation Results of TR}

\subsubsection{TR for Uniform Rate Hyetograph}

(1) TR for TIVUHs. $\mathrm{UH}_{5 \mathrm{~mm}}, \mathrm{UH}_{10 \mathrm{~mm}}, \mathrm{UH}_{20 \mathrm{~mm}}$, and $\mathrm{UH}_{30 \mathrm{~mm}}$ are used to analyze the relationship between TR and $\mathrm{Pa}$. The TR-Pa curves of four UHs are illustrated in Figure 3. The computed TR value is small when a $\mathrm{UH}$ with a large peak (such as $\mathrm{UH}_{30 \mathrm{~mm}}$ ) is used at each $\Delta t$, and the computed TR value is large when $\mathrm{UH}$ with a small peak (such as $\mathrm{UH}_{5 \mathrm{~mm}}$ ) is used at each $\Delta t$. It is concluded that UHs influence significantly the TR computational results.

(2) TR for TVUHs. The derived TR-Pa curve for TVUHs is illustrated in Figure 3. It can be seen that when $\mathrm{Pa}$ is $130 \mathrm{~mm}$ (antecedent soil water content being saturated), the TR value of TVUHs is equal to that of $\mathrm{UH}_{10 \mathrm{~mm}}$, meaning $\mathrm{UH}_{10 \mathrm{~mm}}$ is used for all $\Delta t$. When Pa decreases (for example to $40 \mathrm{~mm}$ ), the net rainfall values of initial time intervals become less than $7.5 \mathrm{~mm}$ because of rainfall loss and $\mathrm{UH}_{5 \mathrm{~mm}}$ is used, so that TR value of TVUHs is larger than that computed using $\mathrm{UH}_{10 \mathrm{~mm}}$ at all $\Delta t$.

\subsubsection{TR for Nonuniform Hyetograph}

(1) Hyetograph types. For a given combination of $\mathrm{Pa}$ and $D$, the reason a minor rainfall value is necessary to cause flooding is that, for the same rainfall volume, different hyetograph types form different hydrographs and peak

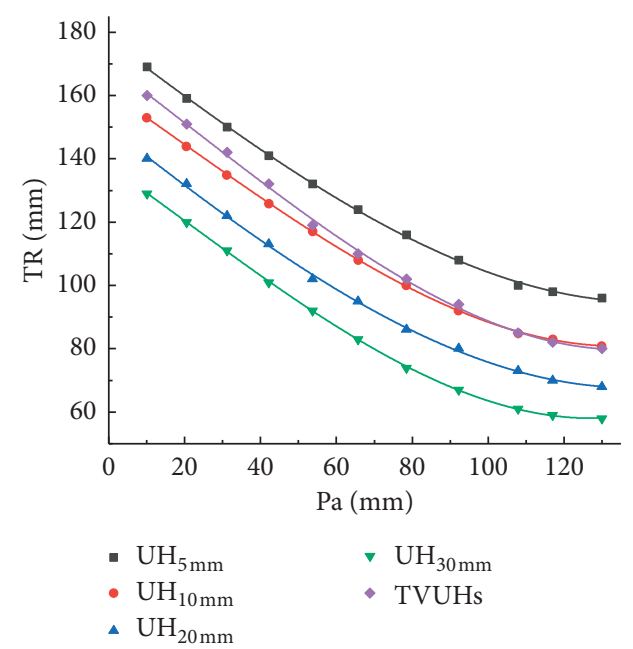

Figure 3: TR-Pa curves $(D=5 \mathrm{~h})$.

values. Consequently, to form the same peak value, different hyetograph types require different rainfall values. Therefore, for a given combination of $\mathrm{Pa}$ and $D$, different hyetograph types have different TR values. The calculation of CR value is to determine the minimum TR value. If the rainfall hyetograph corresponding to the CR can be determined, the watershed hydrological model can be used to derive directly the CR value by trial and error method.

Three synthetic hyetograph types characterized by linearly increasing rate, linearly decreasing rate, and uniform rate are taken into account in this study. For a linearly increasing hyetograph, the ratios of each time interval rainfall value to total rainfall value are calculated as shown in Figure 4 and Table 5 (only that of $D=1-5 \mathrm{~h}$ is listed).

(2) TR for TIVUHs. $\mathrm{UH}_{5 \mathrm{~mm}}$ and $\mathrm{UH}_{30 \mathrm{~mm}}$ are selected to compute the TR-Pa curves of three hyetographs as shown in Figures 5(a) and 5(b), respectively. The effect of $\mathrm{Pa}$ on rainfall loss of initial rainfall time intervals is obvious. From the maximum net rainfall intensity point of view, the last time interval of linearly increasing hyetograph is the largest of the three hyetograph types. Therefore, for the same UH, whatever the Pa value, the TR value of increasing hyetograph is the smallest, being consistent with previous research results $[16,17]$.

(3) TR for TVUHs. Using TVUH, TR-Pa curves of three hyetographs are computed as shown in Figure 6. The TR value corresponding to the increasing hyetograph is the smallest. Results show that the TR value for increasing hyetograph is the smallest whether TVUHs or TIVUHs are used.

(4) Comparison of TR values for different UHs. For the increasing hyetograph, TR-Pa curves of different UHs are derived as shown in Figure 7. For the same Pa, TR value decreases with the increase of $\mathrm{UH}$ peak rate. The gradient of TR with $\mathrm{Pa}$ of TVUHs is smaller than that of TIVUHs. 


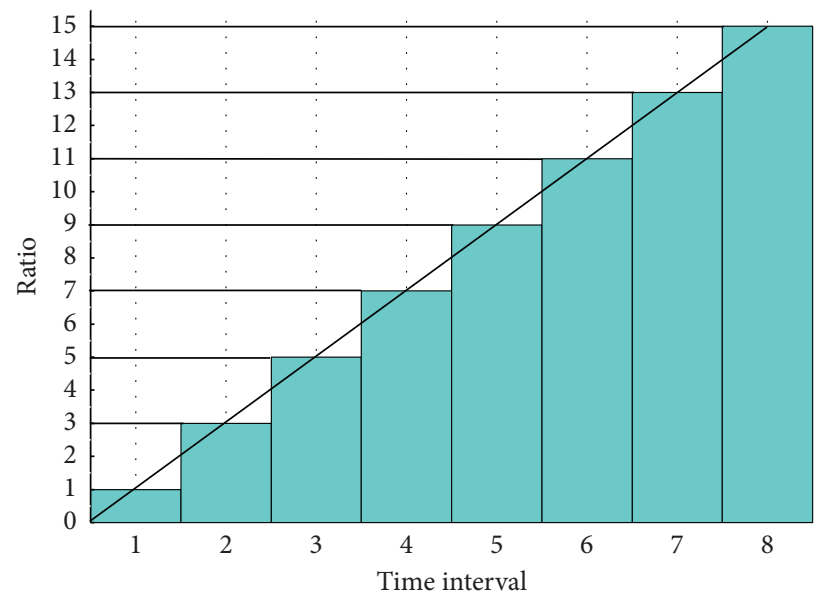

FIGURE 4: Distribution of linearly increasing hyetograph.

TABLE 5: Distribution of linearly increasing hyetograph.

\begin{tabular}{|c|c|c|c|c|c|c|c|c|c|}
\hline \multirow{2}{*}{ No. of $\Delta t$} & \multicolumn{9}{|c|}{$D(\mathrm{~h})$} \\
\hline & 1 & 1.5 & 2 & 2.5 & 3 & 3.5 & 4 & 4.5 & 5 \\
\hline 1 & $1 / 4$ & $1 / 9$ & $1 / 16$ & $1 / 25$ & $1 / 36$ & $1 / 49$ & $1 / 64$ & $1 / 81$ & $1 / 100$ \\
\hline 2 & $3 / 4$ & $1 / 3$ & $3 / 16$ & $3 / 25$ & $1 / 12$ & $3 / 49$ & $1 / 21$ & $1 / 27$ & $3 / 100$ \\
\hline 3 & & $5 / 9$ & $5 / 16$ & $1 / 5$ & $5 / 36$ & $5 / 49$ & $5 / 64$ & $5 / 81$ & $1 / 20$ \\
\hline 4 & & & $7 / 16$ & $7 / 25$ & $7 / 36$ & $1 / 7$ & $7 / 64$ & $7 / 81$ & $7 / 100$ \\
\hline 5 & & & & $9 / 25$ & $1 / 4$ & $9 / 49$ & $9 / 64$ & $1 / 9$ & $9 / 100$ \\
\hline 6 & & & & & $11 / 36$ & $11 / 49$ & $11 / 64$ & $11 / 81$ & $11 / 100$ \\
\hline 7 & & & & & & $13 / 49$ & $13 / 64$ & $13 / 81$ & $13 / 100$ \\
\hline 8 & & & & & & & $15 / 64$ & $5 / 27$ & $3 / 20$ \\
\hline 9 & & & & & & & & $17 / 81$ & $17 / 100$ \\
\hline 10 & & & & & & & & & $19 / 100$ \\
\hline$\Sigma$ & 1 & 1 & 1 & 1 & 1 & 1 & 1 & 1 & 1 \\
\hline
\end{tabular}

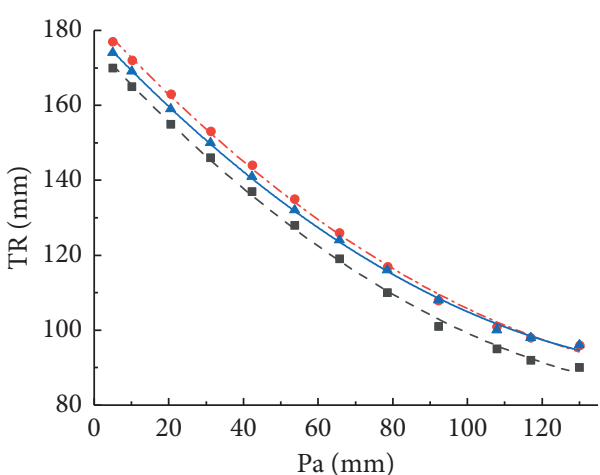

- Increasing hyetograph

- Decreasing hyetograph

A Uniform hyetograph

(a)

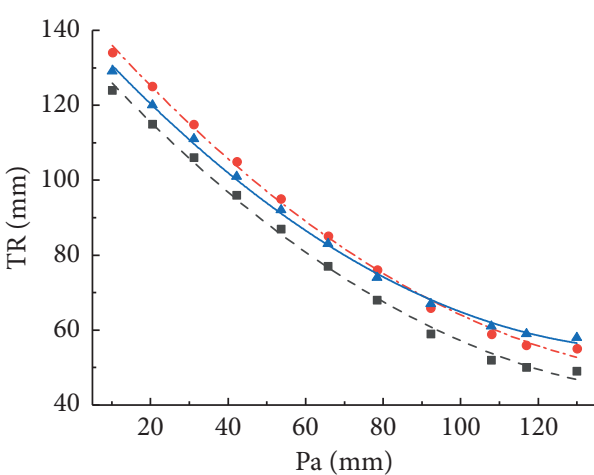

- Increasing hyetograph

- Decreasing hyetograph

$\Delta$ Uniform hyetograph

(b)

FIGURE 5: TR-Pa curves of (a) $\mathrm{UH}_{5 \mathrm{~mm}}$ and (b) $\mathrm{UH}_{30 \mathrm{~mm}}$

According to the literature [18], better simulation results can be obtained when the TVUH method is used. Ultimately, the combination of TVUHs and increasing hyetograph is used to compute the TR value which can be taken as the $\mathrm{CR}$ value.

\subsection{Computation Results of CR Value}

4.4.1. CR-Pa Curves. The relationships between $\mathrm{CR}$ value and $\mathrm{Pa}$ (CR-Pa curves) for different durations (only $1-7 \mathrm{~h}$ ) are derived as shown in Figure 8. 


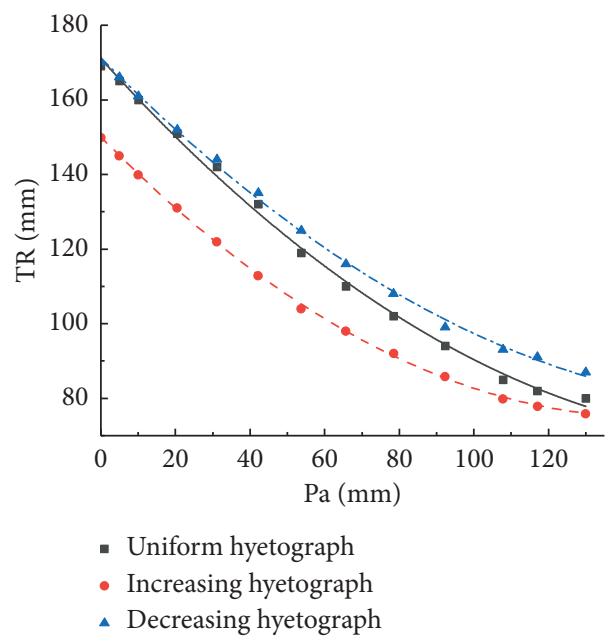

Figure 6: TR-Pa curves of TVUHs for different hyetographs.

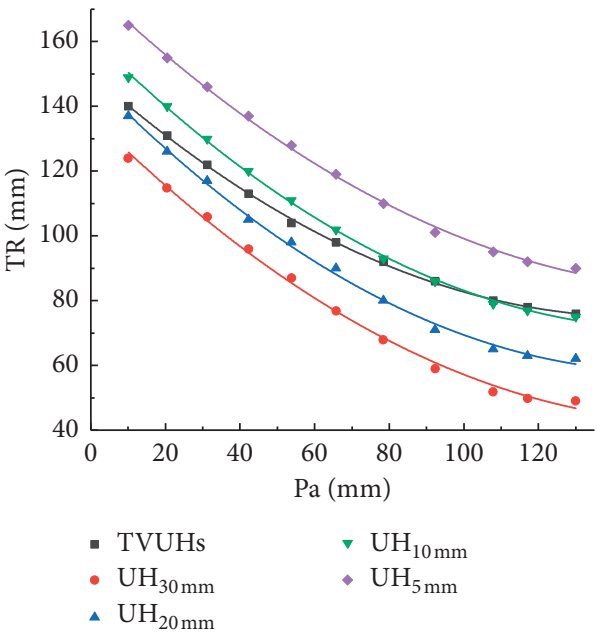

FIgURE 7: TR-Pa curves of different UHs.

4.4.2. $C R-D$ Curves. Due to the obvious influence of $\mathrm{Pa}$ on CR value, the relationships between $\mathrm{CR}$ and $D$ (CR-D curves) are derived, respectively, for Pa being $5 \mathrm{~mm}, 10 \mathrm{~mm}$, $15 \mathrm{~mm}, \ldots, 130 \mathrm{~mm}$ as shown in Figure 9 which can be used for real-time flash flood warning.

\section{Application of CR Values}

5.1. Warning Process. In the process of real-time flash flood warning, the first step is to compute Pa value and choose the CR- $D$ curve. The second step is to compute accumulated rainfall $P 1$ of $D 1$ and compare it with the CR of $D 1$ beginning from the smallest time duration (e.g., $D 1=1 \mathrm{~h}$ ). If $P 1$ is larger than or equal to CR, a warning should be issued. Otherwise, accumulated rainfall $P 2$ of the next time duration $D 2$ $(D 2=1.5 \mathrm{~h})$ is computed and the comparison between $P 2$ and the CR of $D 2$ is performed to decide whether a warning should be issued.

5.2. Analysis of Warning Results. In this study, 12 historical flood events in Tanjia River basin (including 11 events whose peak discharge is greater than critical discharge and 1 event whose peak discharge is less than but close to critical discharge) are selected. Pa computation results for each rainfall event are shown in Table 6. According to the $\mathrm{Pa}$ of each event, the CR-D relationship is selected. The warning process and warning results are shown in Figure 10 and Table 6 . The warning result statistics are shown in Table 7.

On the basis of Table 7, four index values are as follows:

$$
\begin{aligned}
& \operatorname{HAR}=\frac{N_{\mathrm{X}}}{N_{\mathrm{X}}+N_{\mathrm{Y}}}=\frac{10}{10+1}=91 \%, \\
& \mathrm{MAR}=\frac{N_{\mathrm{Y}}}{N_{\mathrm{X}}+N_{\mathrm{Y}}}=\frac{1}{10+1}=9 \%,
\end{aligned}
$$

$$
\begin{aligned}
& \mathrm{FAR}=\frac{N_{\mathrm{Z}}}{N_{\mathrm{X}}+N_{\mathrm{Z}}}=\frac{0}{10+0}=0, \\
& \mathrm{CSI}=\frac{N_{\mathrm{X}}}{N_{\mathrm{X}}+N_{\mathrm{Y}}+N_{\mathrm{Z}}}=\frac{10}{10+1+0}=0.91 .
\end{aligned}
$$

It can be seen that 10 events can successfully be issued warnings before observed discharge exceeds critical discharge, the lead time ranges from $0.5 \mathrm{~h}$ to $2 \mathrm{~h}$, and the hit rate is $91 \%$. One event failed to alarm, for a missed alarm rate of $9 \%$.

The observed peak discharge value of event 19830722 is $354 \mathrm{~m}^{3} / \mathrm{s}$, exceeding critical discharge by only $1.1 \%$ and a missed alarm does not happen. The observed peak discharge of event 19980803 is $330 \mathrm{~m}^{3} / \mathrm{s}$, the difference with critical discharge is only $5.7 \%$, and false alarm did not happen.

The observed peak discharge of event 19890808 is $359 \mathrm{~m}^{3} / \mathrm{s}$, exceeding critical discharge by only $1.1 \%$, and a missed alarm event happens. According to rainfall depth measured at each rain gauge, it can be found that although the mean areal rainfall value is only $65 \mathrm{~mm}$, there is a large 

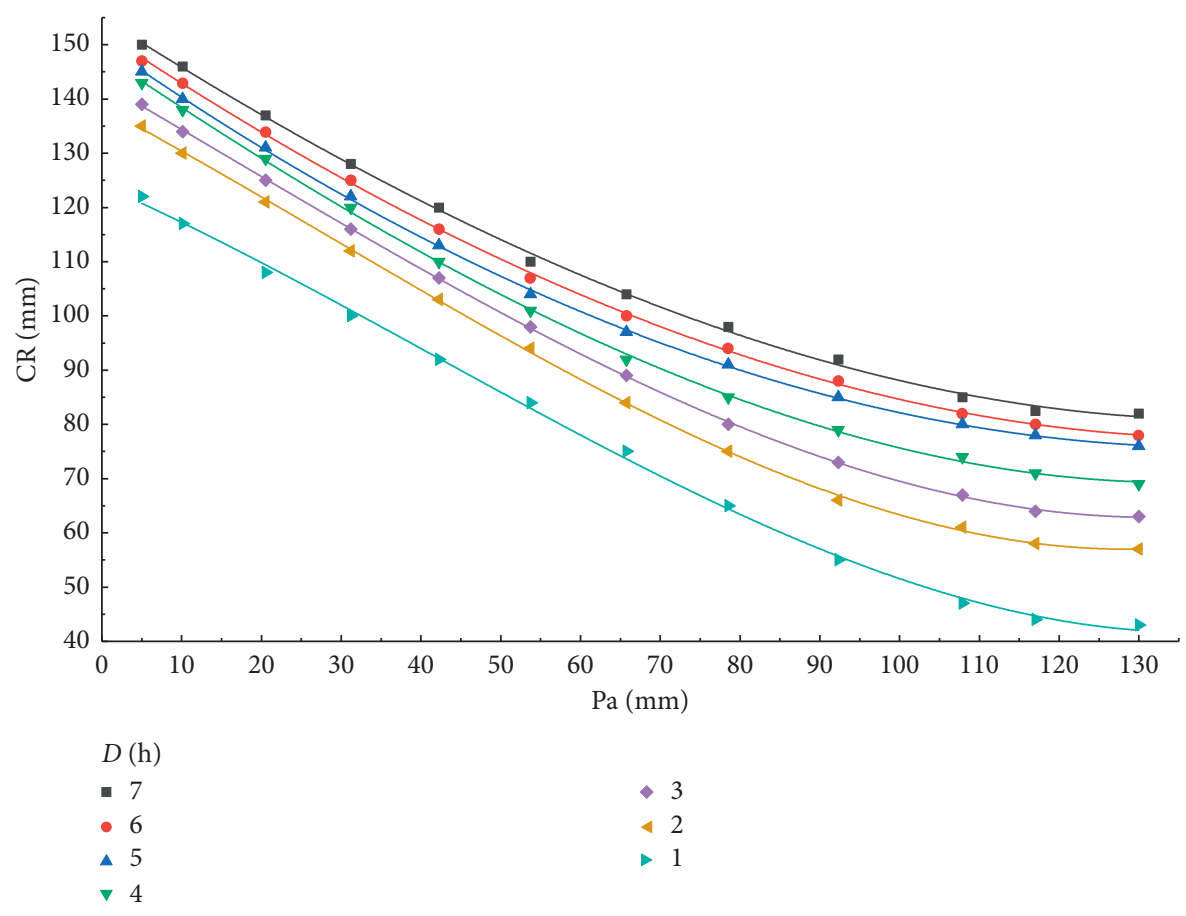

Figure 8: CR-Pa curves of different durations.
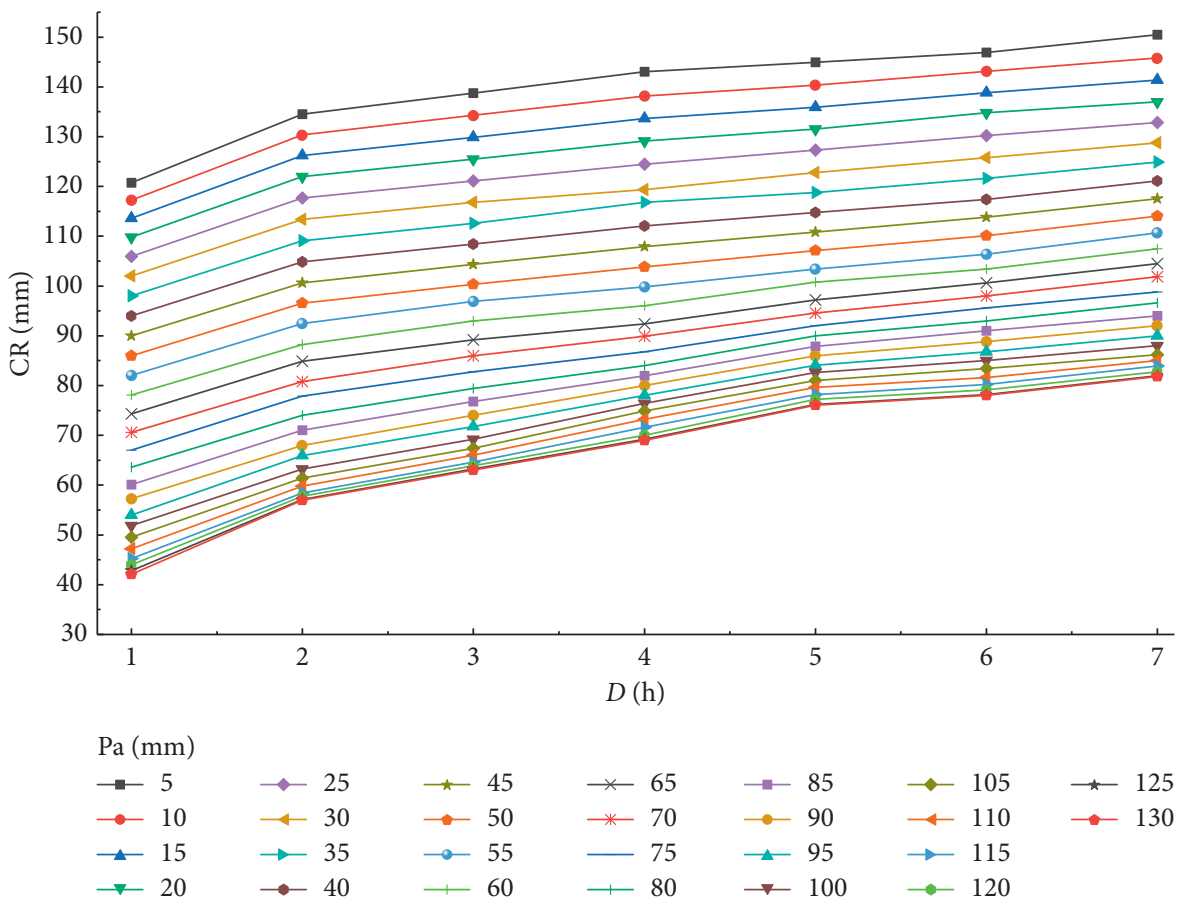

Figure 9: CR-D curves of different Pa.

single gauge rainfall value whose rainfall depth is $142 \mathrm{~mm}$ (Xindian gauge). A noteworthy disadvantage of CR-based warning method is that the mean areal rainfall is used and the spatial distribution of rainfall is not taken into account.
5.3. Effect of CR Values on Warning Results. Six combinations of UHs and hyetographs are selected as shown in Table 8 . CR-Pa curves $(D=5 \mathrm{~h})$ of the six combinations are illustrated in Figure 11. Three flood events including 19860715,19920505 , and 19820720 (rainfall values of $5 \mathrm{~h}$ and 
TABLE 6: Warning results of 12 flood events.

\begin{tabular}{|c|c|c|c|c|c|c|c|}
\hline Flood no. & $\mathrm{Pa}(\mathrm{mm})$ & $D(\mathrm{~h})$ & $P(\mathrm{~mm})$ & Warning & Lead time (h) & Results & Status \\
\hline 19820718 & 50 & 7 & 130 & Warning & 1 & Hit & $\mathrm{X}$ \\
\hline 19820723 & 110 & 3.5 & 77 & Warning & 2 & Hit & $\mathrm{X}$ \\
\hline 19830722 & 40 & 6.5 & 120 & Warning & 2 & Hit & $\mathrm{X}$ \\
\hline 19860715 & 45 & 5 & 117 & Warning & 1 & Hit & $\mathrm{X}$ \\
\hline 19860722 & 95 & 1.5 & 74 & Warning & 2 & Hit & $\mathrm{X}$ \\
\hline 19870713 & 20 & 2.5 & 152 & Warning & 1.5 & Hit & $\mathrm{X}$ \\
\hline 19890808 & 40 & 4 & 78 & No warning & & Missed & $\mathrm{Y}$ \\
\hline 19920505 & 50 & 5 & 110 & Warning & 0.5 & Hit & $\mathrm{X}$ \\
\hline 19950512 & 50 & 3 & 103 & Warning & 2 & Hit & $\mathrm{X}$ \\
\hline 19960717 & 85 & 4.5 & 87 & Warning & 1 & Hit & $\mathrm{X}$ \\
\hline 19970630 & 65 & 5 & 113 & Warning & 1.5 & Hit & $\mathrm{X}$ \\
\hline 19980803 & 55 & 6 & 103 & No warning & & & W \\
\hline
\end{tabular}

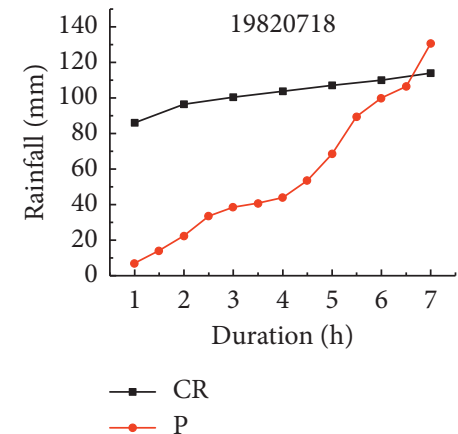

(a)

Time (0.5h)

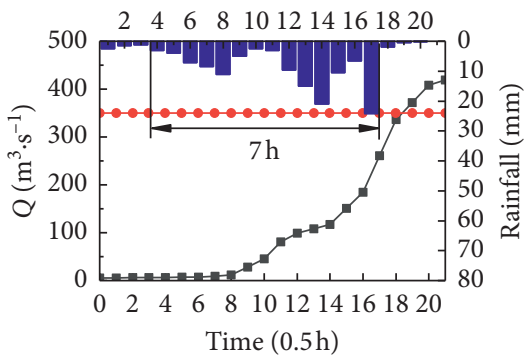

$\begin{array}{ll}\longrightarrow & Q_{\mathrm{o}} \\ \longrightarrow & \text { CQ } \\ & \text { Rainfall } 19820718\end{array}$

(d)

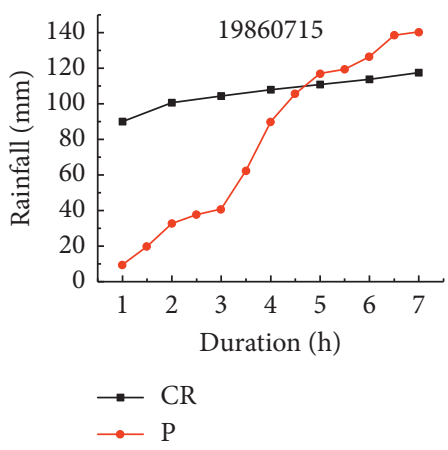

(g)

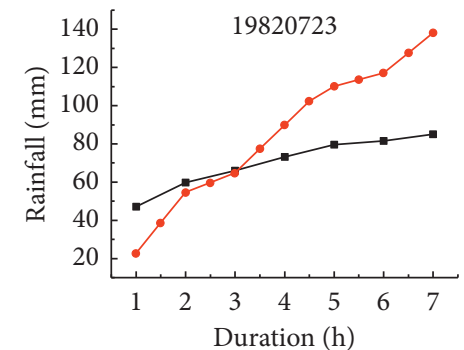

$\rightarrow$ CR

(b)

Time $(0.5 \mathrm{~h})$

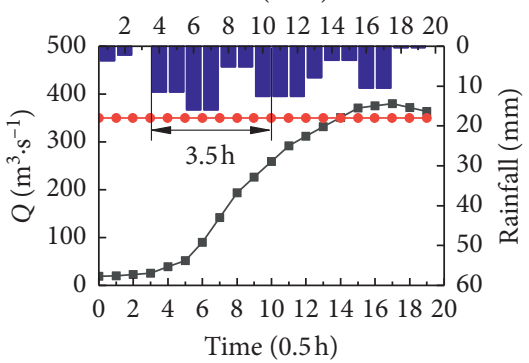

$\rightarrow Q_{0}$

$\rightarrow$ CQ

Rainfall 19820723

(e)

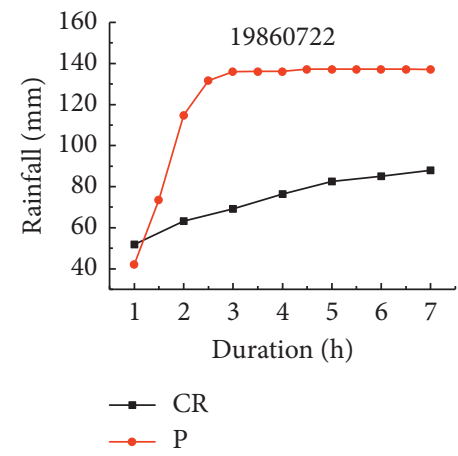

(h)

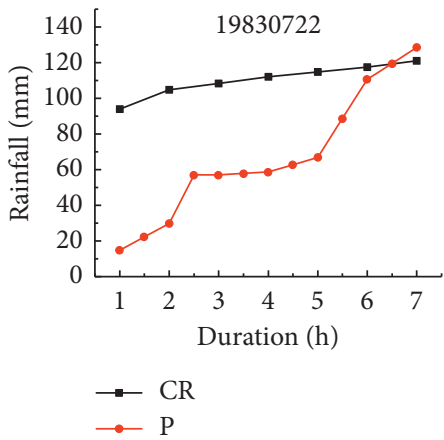

(c)

Time $(0.5 \mathrm{~h})$

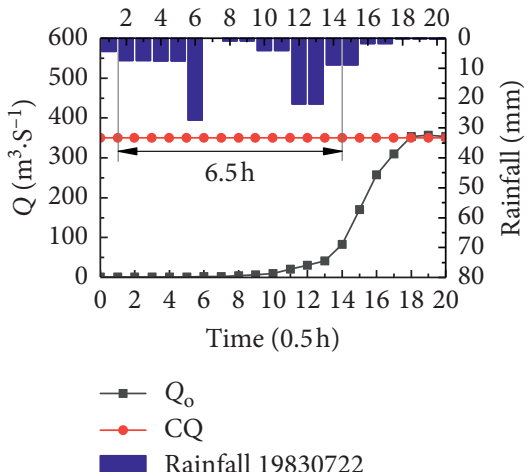

(f)

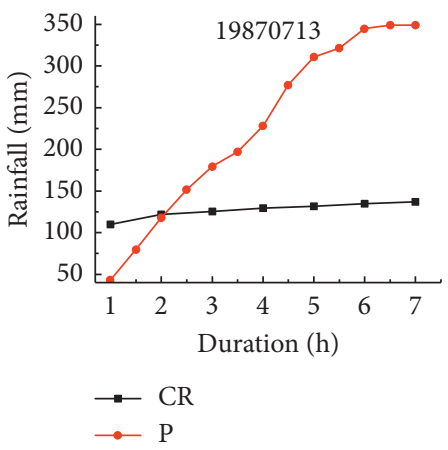

(i)

Figure 10: Continued. 


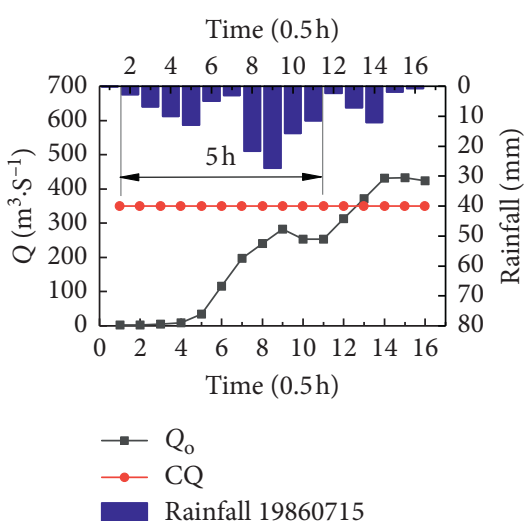

(j)

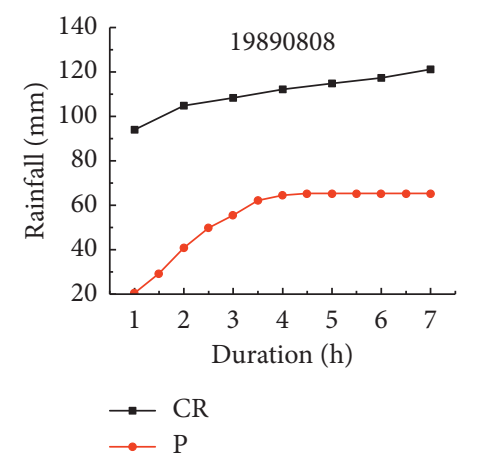

(m)

Time (0.5h)

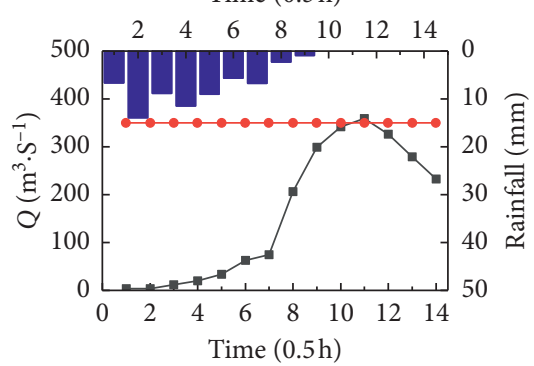

$\begin{aligned} \because & Q_{\mathrm{o}} \\ \rightarrow & \text { CQ } \\ & \text { Rainfall } 19890808\end{aligned}$

(p)

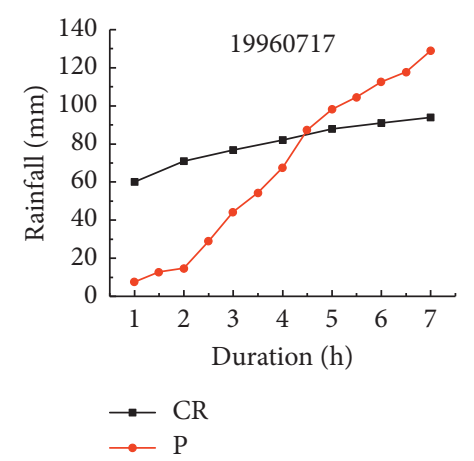

(s)

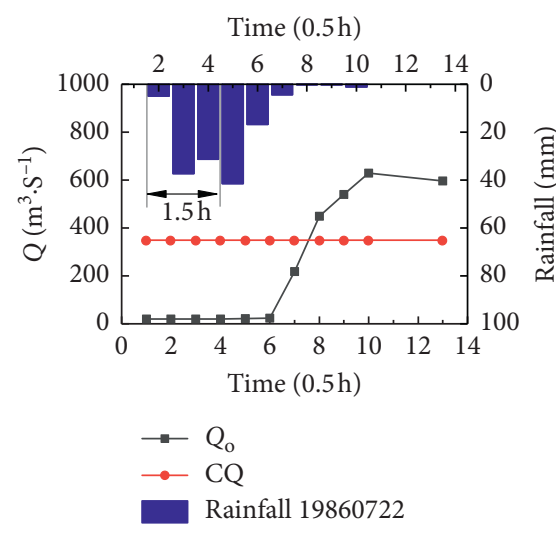

(k)

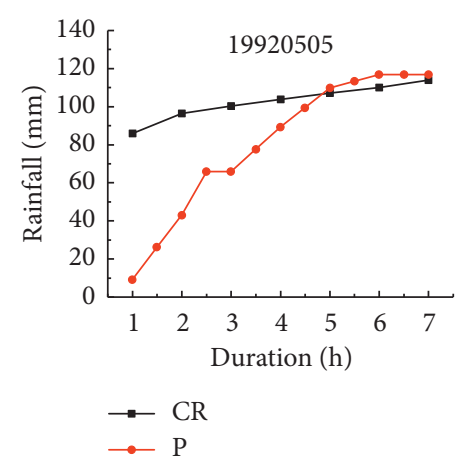

(n)

Time (0.5h)

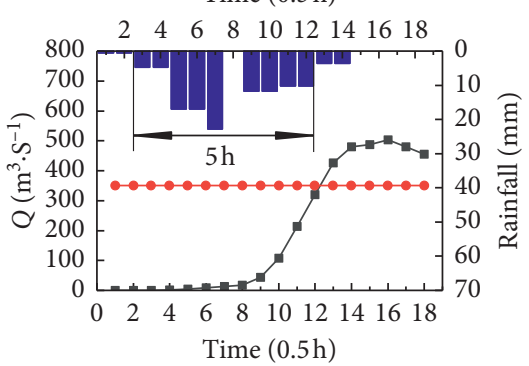

$\rightarrow Q_{0}$

$\rightarrow \mathrm{CQ}$

Rainfall 1992050

(q)

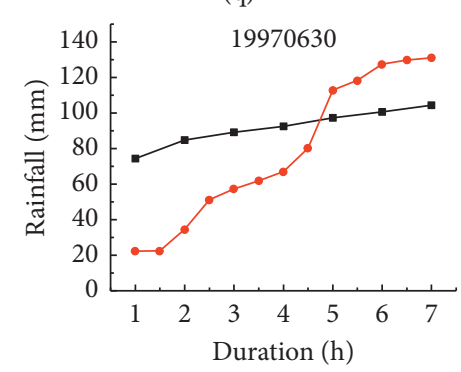

$\rightarrow \mathrm{CR}$
$\rightarrow \mathrm{P}$

(t)

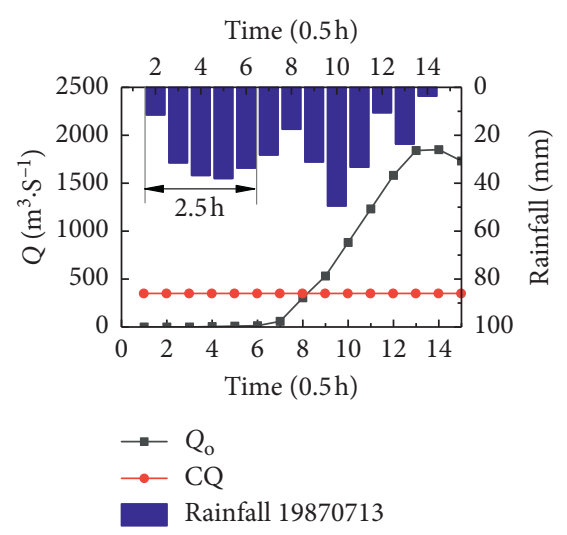

(1)

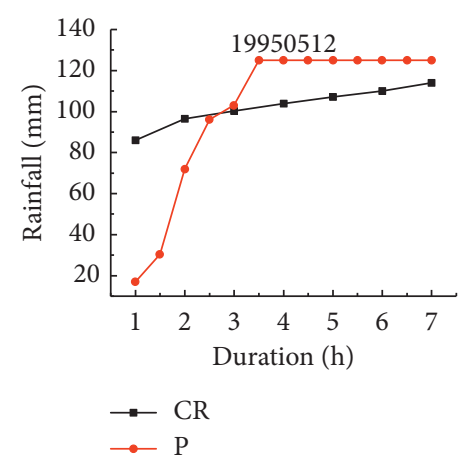

(o)

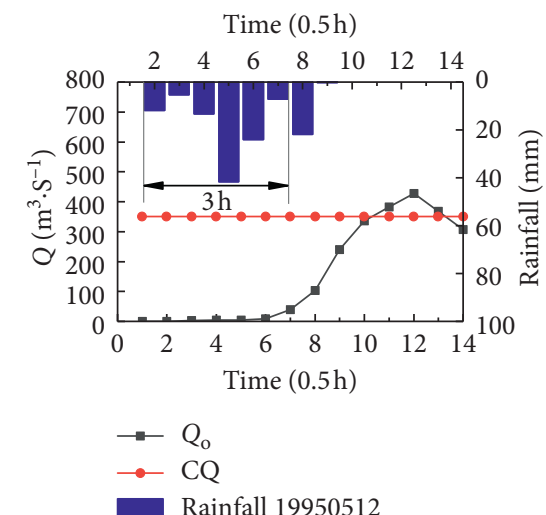

(r)

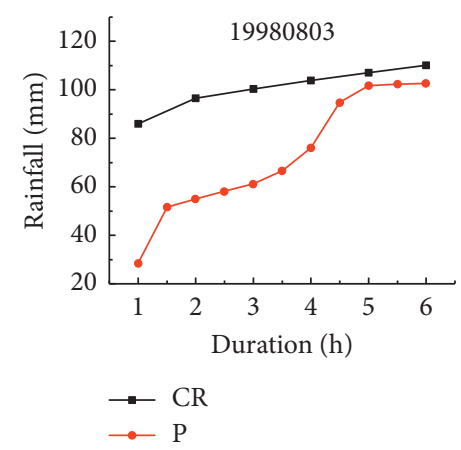

(u)

Figure 10: Continued. 


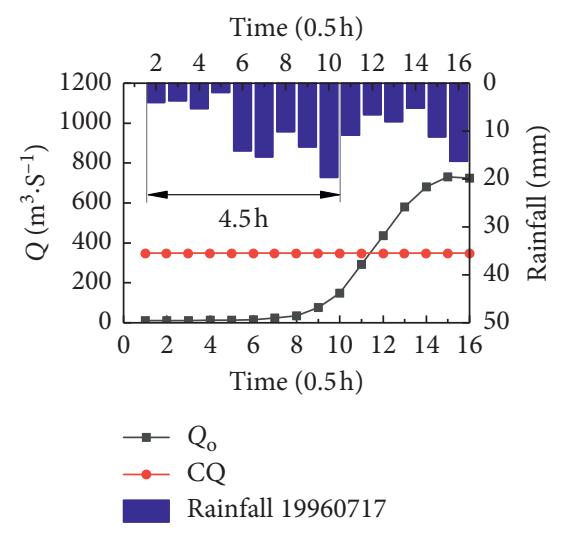

(v)

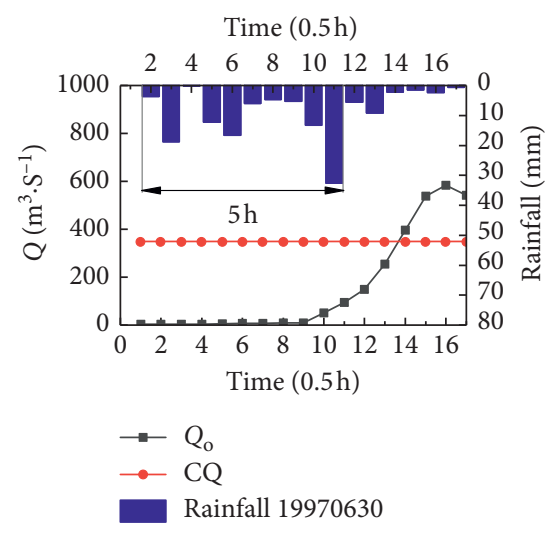

(w)

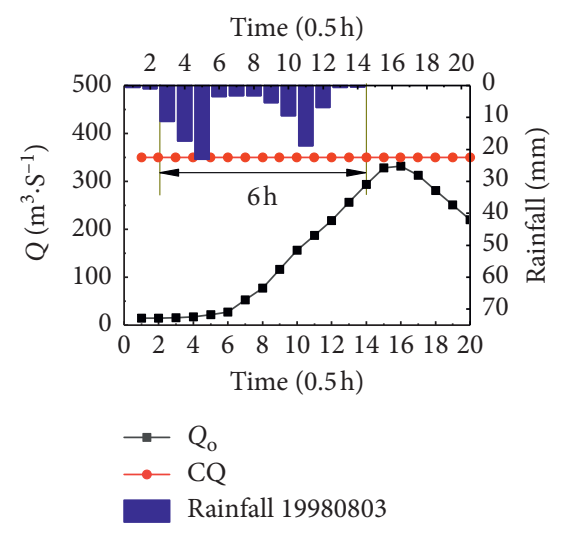

(x)

Figure 10: Rainfall, critical discharge (CQ), hydrographs observed $\left(Q_{o}\right)$, and comparison between CR and accumulated rainfall $(P)$.

TABLE 7: Statistics of warning results.

\begin{tabular}{lcc}
\hline Observations & \multicolumn{2}{c}{ Forecasts } \\
& Warning & No warning \\
\hline Event & 10 & 1 \\
Nonevent & 0 & 1 \\
\hline
\end{tabular}

TABLE 8: Combination of UHs and hyetographs.

\begin{tabular}{lcc}
\hline Combination & Hyetograph & $\mathrm{UH}$ \\
\hline C1 & Uniform & $\mathrm{UH}_{10 \mathrm{~mm}}$ \\
C2 & Increasing & $\mathrm{UH}_{10 \mathrm{~mm}}$ \\
C3 & Uniform & $\mathrm{UH}_{20 \mathrm{~mm}}$ \\
C4 & Increasing & $\mathrm{UH}_{20 \mathrm{~mm}}$ \\
C5 & Uniform & $\mathrm{TVUHs}$ \\
C6 & Increasing & TVUHs \\
\hline
\end{tabular}

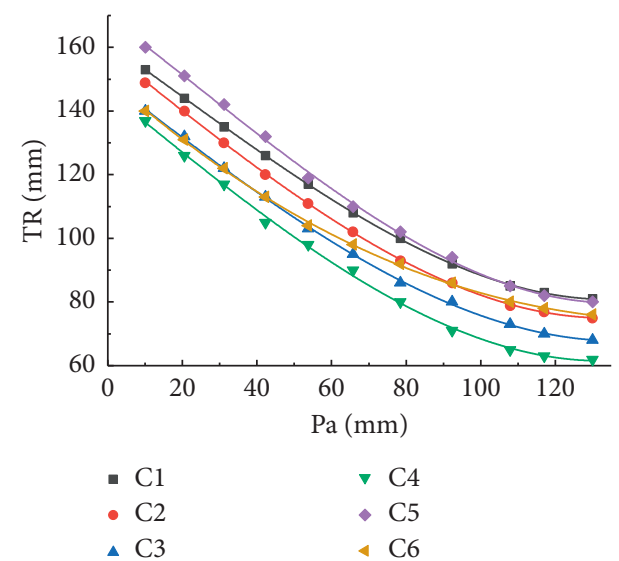

Figure 11: CR-Pa curves of six combinations of UHs and hyetographs.

$6 \mathrm{~h}$ before time to peak is $69 \mathrm{~mm}$ and $76 \mathrm{~mm}$, respectively, with peak discharge being $296 \mathrm{~m}^{3} / \mathrm{s}$ ) are used. The modeled warning results of three flood events are shown in Table 9. It can be seen that only the combination of TVUHs and increasing hyetograph has no missed alarms or false alarms.
TABLE 9: Results of modeled warning.

\begin{tabular}{cccccccc}
\hline Flood no. & $\mathrm{Pa}(\mathrm{mm})$ & $\mathrm{C} 1$ & $\mathrm{C} 2$ & $\mathrm{C} 3$ & $\mathrm{C} 4$ & $\mathrm{C} 5$ & $\mathrm{C6}$ \\
\hline 19860715 & 45 & $\mathrm{Y}$ & $\mathrm{Y}$ & $\mathrm{Y}$ & $\mathrm{X}$ & $\mathrm{X}$ & $\mathrm{X}$ \\
19920505 & 50 & $\mathrm{Y}$ & $\mathrm{Y}$ & $\mathrm{Y}$ & $\mathrm{X}$ & $\mathrm{X}$ & $\mathrm{X}$ \\
19820720 & 130 & $\mathrm{~W}$ & $\mathrm{~W}$ & $\mathrm{~W}$ & $\mathrm{Z}$ & $\mathrm{Z}$ & $\mathrm{W}$ \\
\hline
\end{tabular}

\section{Conclusions}

The aim of this work is to investigate the effect of UHs and rainfall hyetographs on TR/CR values of flash flood and to propose a computation method for CR estimates. Using Xin'anjiang Model, the relationships between TR and $\mathrm{Pa}$ (TR-Pa curves) of different UHs (TIVUHs and TVUHs) were derived for three rainfall hyetograph types (linearly increasing, linearly decreasing, and uniform). The effect of UHs and hyetographs on TR estimates was investigated. Six combinations of two hyetograph types (linearly increasing and uniform) and three UHs $\left(\mathrm{UH}_{10 \mathrm{~mm}}, \mathrm{UH}_{20 \mathrm{~mm}}\right.$, and TVUHs) were used to investigate the effect of UHs and hyetographs on warning results. The combination of linearly increasing hyetograph and TVUHs was determined to be optimum for computing CR estimate. Relationships between $\mathrm{CR}$ values and durations (CR-D curves) of different initial soil moisture conditions were derived and used to model warning 12 events with a hit rate of $91 \%$ and missed alarm rate being $9 \%$. Conclusions may be made as follows:

(1) When other conditions are the same, the TR value corresponding to the linearly increasing hyetograph is the smallest. Because CR is the minimum rainfall value necessary to cause flooding, the increasing hyetograph corresponds to CR.

(2) $\mathrm{UH}$ is the most widely accepted tool for routing surface runoff used in TR/CR value estimation. When TIVUHs are used to calculate TR value, the $\mathrm{UH}$ selection is very important. The larger the $\mathrm{UH}$ peak rate is, the smaller the corresponding TR value is. The smaller the $\mathrm{UH}$ peak value is, the larger the corresponding TR value is. So, when using TIVUH, the TR/CR estimate is obviously indeterminate. The 
simulation result of historical flood events using TVUHs is better than that using TIVUHs. Therefore, it is proposed to use TVUHs to calculate CR value.

(3) TR resulted from the combination of TVUHs and linearly increasing hyetograph conforms to the meaning of CR and the value is closer to the minimum rainfall value necessary to cause flooding. Therefore, the TR computed from the combination of TVUHs and linearly increasing hyetograph can be taken directly as the CR value.

(4) Modeled warning results of 12 historical flood events show that the CR value computed from the combination of TVUHs and linearly increasing hyetograph can lead to near ideal flash flood warning results.

\section{Data Availability}

The precipitation and discharge data from 1954 to 2001 used in this research are provided by Henan Hydrology Bureau, China. DEM data in $30 \mathrm{~m}$ resolution can be freely accessed from CGIAR-CSI SRTM project on the website http://srtm. csi.cgiar.org/.

\section{Conflicts of Interest}

The authors declare that they have no conflicts of interest.

\section{Acknowledgments}

This study was supported by the National Natural Science Foundation of China (nos. 51609242 and 51979271), the Fundamental Research Funds for the Central Universities (no. 2015XKMS034), and the China Postdoctoral Science Foundation (2018M632333). This project was funded by the Priority Academic Program Development (PAPD) of Jiangsu Higher Education Institutions.

\section{References}

[1] T. M. Carpenter, J. A. Sperfslage, K. P. Georgakakos, T. Sweeney, and D. L. Fread, "National threshold runoff estimation utilizing gis in support of operational flash flood warning systems," Journal of Hydrology, vol. 224, no. 1-2, pp. 21-44, 1999.

[2] P. Javelle, C. Fouchier, P. Arnaud, and J. Lavabre, "Flash flood warning at ungauged locations using radar rainfall and antecedent soil moisture estimations," Journal of Hydrology, vol. 394, no. 1-2, pp. 267-274, 2010.

[3] V. Montesarchio, E. Ridolfi, F. Russo, and F. Napolitano, "Rainfall threshold definition using an entropy decision approach and radar data," Natural Hazards and Earth System Science, vol. 11, no. 7, pp. 2061-2074, 2011.

[4] M. Borga, P. Boscolo, F. Zanon, and M. Sangati, "Hydrometeorological analysis of the 29 august 2003 flash flood in the eastern Italian alps," Journal of Hydrometeorology, vol. 8, pp. 18-22, 2007.

[5] C. Corral, M. Berenguer, D. Sempere-Torres, L. Poletti, F. Silvestro, and N. Rebora, "Comparison of two early warning systems for regional flash flood hazard forecasting," Journal of Hydrology, vol. 572, pp. 603-619, 2019.
[6] H. M. Mogil, J. C. Monro, and H. S. Groper, "NWS's flash flood warning and disaster preparedness programs," Bulletin of the American Meteorological Society, vol. 59, no. 6, pp. 690-699, 1978.

[7] M. L. V. Martina, E. Todini, and A. Libralon, "A bayesian decision approach to rainfall thresholds based flood warning," Hydrology and Earth System Sciences, vol. 2, no. 6, pp. 413426, 2006.

[8] P. Javelle, J. Demargne, D. Defrance, J. Pansu, and P. Arnaud, "Evaluating flash-flood warnings at ungauged locations using post-event surveys: a case study with the aiga warning system," Hydrological Sciences Journal, vol. 59, no. 7, pp. 13901402, 2014.

[9] S.-J. Wu, C.-T. Hsu, H.-C. Lien, and C.-H. Chang, "Modeling the effect of uncertainties in rainfall characteristics on flash flood warning based on rainfall thresholds," Natural Hazards, vol. 75, no. 2, pp. 1677-1711, 2015.

[10] E. Toth, "Estimation of flood warning runoff thresholds in ungauged basins with asymmetric error functions," Hydrology and Earth System Sciences, vol. 20, no. 6, pp. 2383-2394, 2016.

[11] F. Pappenberger, J. Bartholmes, J. Thielen, H. L. Cloke, R. Buizza, and A. D. Roo, "New dimensions in early flood warning across the globe using using grand-ensemble weather predictions," Geophysical Research Letters, vol. 35, pp. 1-7, 2008.

[12] J. S. Verkade and M. G. F. Werner, "Estimating the benefits of single value and probability forecasting for flood warning," Hydrology and Earth System Sciences Discussions, vol. 8, no. 4, pp. 6639-6681, 2011.

[13] K. P. Georgakakos, "Analytical results for operational flash flood guidance," Journal of Hydrology, vol. 317, no. 1-2, pp. 81-103, 2006.

[14] H. A. P. Hapuarachchi, Q. J. Wang, and T. C. Pagano, “A review of advances in flash flood forecasting," Hydrological Processes, vol. 25, no. 18, pp. 2771-2784, 2011.

[15] Q. Miao, D. Yang, H. Yang, and Z. Li, "Establishing a rainfall threshold for flash flood warnings in China's mountainous areas based on a distributed hydrological model," Journal of Hydrology, vol. 541, pp. 371-386, 2016.

[16] V. Montesarchio, F. Lombardo, and F. Napolitano, "Rainfall thresholds and flood warning: an operative case study," Natural Hazards and Earth System Sciences, vol. 9, no. 1, pp. 135-144, 2009.

[17] A. Forestieri, D. Caracciolo, E. Arnone, and L. V. Noto, "Derivation of rainfall thresholds for flash flood warning in a Sicilian basin using a hydrological model," Procedia Engineering, vol. 154, pp. 818-825, 2016.

[18] F. Z. Kong and L. Guo, "A method of deriving time-variant distributed unit hydrograph," Advances in Water Science, vol. 30, no. 4, pp. 477-484, 2019.

[19] D. Norbiato, M. Borga, S. Degli Esposti, E. Gaume, and S. Anquetin, "Flash flood warning based on rainfall thresholds and soil moisture conditions: an assessment for gauged and ungauged basins," Journal of Hydrology, vol. 362, no. 3-4, pp. 274-290, 2008.

[20] M. Diakakis, "Rainfall thresholds for flood triggering. The case of marathonas in Greece," Natural Hazards, vol. 60, no. 3, pp. 789-800, 2012.

[21] E. Arnone, Y. G. Dialynas, L. V. Noto, and R. L. Bras, "Accounting for soil parameter uncertainty in a physically based and distributed approach for rainfall-triggered landslides," Hydrological Processes, vol. 30, pp. 17-22, 2016.

[22] D. Norbiato, M. Borga, and R. Dinale, "Flash flood warning in ungauged basins by use of the flash flood guidance and model- 
based runoff thresholds," Meteorological Applications, vol. 16, no. 1 , pp. 65-75, 2009.

[23] S. K. Singh, "Transmuting synthetic unit hydrographs into gamma distribution," Journal of Hydrologic Engineering, vol. 5, no. 4, pp. 380-385, 2000.

[24] P. K. Bhunya, S. K. Mishra, and R. Berndtsson, "Simplified two-parameter gamma distribution for derivation of synthetic unit hydrograph," Journal of Hydrologic Engineering, vol. 8, pp. 5-8, 2003.

[25] P. K. Singh, S. K. Mishra, and M. K. Jain, "A review of the synthetic unit hydrograph: from the empirical uh to advanced geomorphological methods," Hydrological Sciences Journal, vol. 59, no. 2, pp. 239-261, 2014.

[26] I. Rodríguez-Iturbe and J. B. Valdés, "The geomorphologic structure of hydrologic response," Water Resources Research, vol. 15, no. 6, pp. 1409-1420, 1979.

[27] R. Rosso, "Nash model relation to horton order ratios," Water Resources Research, vol. 20, no. 7, pp. 914-920, 1984.

[28] V. K. Gupta and O. J. Mesa, "Runoff generation and hydrologic response via channel network geomorphology - recent progress and open problems," Journal of Hydrology, vol. 102, no. 1-4, pp. 3-28, 1988.

[29] P. S. Naden, "Spatial variability in flood estimation for large catchments: the exploitation of channel network structure," Hydrological Sciences Journal, vol. 37, no. 1, pp. 53-71, 1992.

[30] M. Franchini and P. E. O'Connell, "An analysis of the dynamic component of the geomorphologic instantaneous unit hydrograph," Journal of Hydrology, vol. 175, no. 1-4, pp. 407-428, 1996.

[31] S. Grimaldi, A. Petroselli, G. Alonso, and F. Nardi, "Flow time estimation with spatially variable hillslope velocity in ungauged basins," Advances in Water Resources, vol. 33, no. 10, pp. 1216-1223, 2010.

[32] I. Rodríguez-Iturbe, M. González-Sanabria, and R. L. Bras, “A geomorphoclimatic theory of the instantaneous unit hydrograph," Water Resources Research, vol. 18, no. 4, pp. 877-886, 1982.

[33] I. Rodríguez-Iturbe, M. G. Sanabira, and G. Caamaño, “On the climatic dependence of the iuh: a rainfall-runoff analysis of the nash model and the geomorphoclimatic theory," Water Resources Research, vol. 18, no. 4, pp. 887-903, 1982.

[34] D. R. Maidment, "Application of Geographic Information Systems in Hydrology and Water Resources Management," in Proceedings of the Vienna Conference, vol. 211, IAHS publication, Vienna, Austria, pp. 181-192, April 1993.

[35] D. R. Maidment, F. Olivera, A. Calver, A. Eatherall, and W. Fraczek, "Unit hydrograph derived from a spatially distributed velocity field," Hydrological Processes, vol. 10, no. 6, pp. 831-844, 1996.

[36] A. Ammukutty and B. T. . Nair, "Rainfall runoff modelling using distributed unit hydrograph approach," Ish Journal of Hydraulic Engineering, vol. 15, no. 1, pp. 24-33, 2012.

[37] I. Muzik, "A gis-derived distributed unit hydrograph," in Proceedings of the Vienna Conference-Application of Geographic Information Systems in Hydrology and Water Resources Management, vol. 235, IAHS publication, Vienna, Austria, pp. 453-460, April 1996.

[38] M. H. Ajward and I. Muzik, "A spatially varied unit hydrograph model," Journal of Environmental Hydrology, vol. 8, pp. 1-8, 2000.

[39] Henan Water and Power Survey and Design Institute, Henan Design Storm and Flood Atlas of Medium and Small Basin, Henan Water and Power Survey and Design Institute, Henan, China, 1984.
[40] R. C. Sorrell, "Computing Flood Discharges for Small Ungaged Watersheds," Michigan Department of Natural Resources- Land and Water Management Division, 2008.

[41] M. H. Tewolde and J. C. Smithers, "Flood routing in ungauged catchments using Muskingum methods," Water SA, vol. 32, no. 3, pp. 379-387, 2007.

[42] S. J. Mason and N. E. Graham, "Conditional probabilities, relative operating characteristics, and relative operating levels," Weather and Forecasting, vol. 14, no. 5, pp. 713-725, 1999.

[43] S. Reed, J. Schaake, and Z. Zhang, "A distributed hydrologic model and threshold frequency-based method for flash flood forecasting at ungauged locations," Journal of Hydrology, vol. 337, no. 3-4, pp. 402-420, 2007.

[44] C. Harman, M. Stewardson, and R. DeRose, "Variability and uncertainty in reach bankfull hydraulic geometry," Journal of Hydrology, vol. 351, no. 1-2, pp. 13-25, 2008.

[45] G. V. Wilkerson, "Improved bankfull discharge prediction using 2-year recurrence-period Discharge1," Journal of the American Water Resources Association, vol. 44, no. 1, pp. 243-257, 2008.

[46] P. J. Ward, B. Jongman, F. S. Weiland et al., "Assessing flood risk at the global scale: model setup, results, and sensitivity," Environmental Research Letters, vol. 8, no. 4, pp. 1-10, 2013. 